Taxonomic Note

Correspondence

J. M. Young

youngj@landcareresearch.co.nz

\section{Sinorhizobium versus Ensifer: may a taxonomy subcommittee of the ICSP contradict the Judicial Commission?}

\author{
J. M. Young \\ Landcare Research, Auckland, Private Bag 92170, New Zealand
}

In response to a Request for an Opinion, the Judicial Commission (Opinion 84) confirmed the earlier synonym, Ensifer, as the correct name for the genus better known as Sinorhizobium. The Judicial Commission considered that this decision would not cause sufficient confusion to justify the conservation of the latter name. The Subcommittee on the Taxonomy of Agrobacterium and Rhizobium of the International Committee on Systematics of Prokaryotes (ICSP) publicly disagreed with this conclusion. Was it justified in doing this?
In a Request for an Opinion, Willems et al. (2003) proposed that, although the name Sinorhizobium Chen et al. 1988 emend. De Lajudie et al. 1994 is the later synonym, it should be conserved over Ensifer Casida 1982. In the Request, but preparatory to the formal proposal, they reported comprehensive experimental data that clearly demonstrated the synonymy of the two genera as the basis for the Request. Having demonstrated the synonymy, the authors did not provide an emended description of the genus, as would usually be the case, because the primary intention of the report was the Request for conservation of the name Sinorhizobium. It was probably an editorial mistake to have allowed the Request mechanism to be used to report a synonymy and neither the editors nor the authors foresaw the consequences of the Request being rejected. Had the question of synonymy been reported independently then attention would have focused on the necessity of providing an emended description of the genus, Ensifer, that comprised the characteristics of the two synonyms. Such a description would have made it easier to understand the nomenclatural issues that have emerged.

The primary reasons that Willems et al. (2003) gave for conservation were: that Sinorhizobium was the better known and more widely used name; that inclusion of '...rhizobium' in the name clarified the nature of the organisms; and that the name Ensifer would cause misunderstanding and confusion in the rhizobial science community. Conservation of the name Sinorhizobium had already been endorsed by the Subcommittee on the Taxonomy of Agrobacterium and Rhizobium of the International Committee on Systematics of Prokaryotes (ICSP; the subcommittee) (Lindström \& MartínezRomero, 2002) who claimed there were 'good reasons' for doing so, but did not itemize them.

Abbreviation: ICSP, International Committee on Systematics of Prokaryotes.
In its reply to Willems et al. (2003), the Judicial Commission confirmed that Ensifer took priority as the correct name for the genus but that the reasons urged for conservation were inadequate: 'the transfer of the members of the genus Sinorhizobium to the genus Ensifer would not cause confusion' (Judicial Commission, 2008). This judgement would have been made taking an overview of previous decisions and with an appreciation of the implications of creating a precedent. That names are based on priority is a central principle of the International Code of Nomenclature of Bacteria (the Code, Lapage et al., 1992), now called the International Code of Nomenclature of Prokaryotes (Labeda, 2000), and making an exception in this case would invite a plethora of proposals based on similar local preferences.

The subcommittee (Lindström \& Young, 2009) did not dispute the Judicial Commission's interpretation of the Code; that Ensifer and Sinorhizobium are validly published synonyms of the same taxon and that Ensifer takes priority by reason of earlier publication (Rule 23a). However, it disagreed with the justification: "The transfer of the members of the genus Sinorhizobium to the genus Ensifer would cause great confusion in the scientific community. At a session of the 8th European Nitrogen Fixation Conference on 31 August 2008, an overwhelming majority of those present indicated that they were not in favour of changing the name from Sinorhizobium to Ensifer'. But to what purpose did the subcommittee disagree? The only matter in contention is the extent to which application of the rule would cause significant confusion. When the subcommittee asserts that the correct application of priority would cause 'great confusion in the scientific community', it is unclear what it means, or what it is attempting to achieve. Presumably it does not mean that the subcommittee itself, either as individuals or collectively, is confused. Rather, the subcommittee is championing the wish of what it takes to be the majority of the 
rhizobial science community to retain a name with which it is familiar. Understandably, this community was not in favour of changing the name, but was the confusion so great and was the community so uncomprehending? One can only speculate whether there would have been such a majority if, instead of contradicting it, the subcommittee had endorsed the position of the Judicial Commission and explained the relevant nomenclatural points. It might be expected that an ICSP taxonomic subcommittee would see its role as explaining and defending correct names to the wider scientific community, rather than supporting obsolete nomenclature. Had they done so the 'confusion' among the purported majority might have evaporated. While it is understandable for practising scientists to prefer stable and familiar names, in resisting revisions they deny themselves the insights offered by well-founded reclassification. In this case, it is the insight that, like the 'agrobacteria' (Young, 2008), nitrogen-fixing, nodulating 'sinorhizobia' are a subpopulation of a larger soilinhabiting population, perhaps with many other plasmidborne characteristics. Choosing 'liked' or 'preferred' names reduces them to common names disguised as Code-based authoritative binomial names when they become outdated.

Willems et al. (2003) made the common mistake of assuming that names should be descriptive; in this case that taxa containing nitrogen-fixing, nodulating bacteria should have '...rhizobium' in the stem of their names. The subcommittee has not rebutted this misunderstanding, which very probably plays a significant role in the thinking of the rhizobial science community. Names should not be thought of as being descriptive for the obvious reason that, although they may be so when first proposed, it is very often the case that when taxa are revised or combined, as here, the descriptive name becomes divorced from the emended taxon. This has been explained elsewhere, for example in Sneath (2005) and Young (2008), and should have been explained by the subcommittee.

The subcommittee appears to have fallen into a hopeless logical tangle by its acceptance of the Judicial Commission's decision that the two generic names are synonyms of a single taxon, of which Ensifer is the correct name for the emended genus, while simultaneously supporting the use of the later synonym, Sinorhizobium. It is in this discussion that a emended description of the revised genus would be helpful. Names of species of the genus Sinorhizobium that are already validly published can continue to be used, provided that the intention is to refer to a genus that excludes Ensifer adhaerens, the type strain of the genus Ensifer. However, the subcommittee has endorsed the view that E. adhaerens and Sinorhizobium species are members of a single genus, for which the correct name is Ensifer (Rule 23a). No novel members of the genus Sinorhizobium can be proposed because, unless its generic circumscription is revised, the name is a later synonym of Ensifer. In accepting the Judicial Commission's decision, the subcommittee has rejected the possibility of such an alternative nomenclatural approach. It is hard to see how the advice of the subcommittee can do anything other than considerably increase the very confusion that they seek to avoid. Even if the use of both names for the genus is permissible, scientists using Sinorhizobium terminology face the prospect of referring to both generic names in the same reports as the number of novel species of the genus Ensifer inevitably increases (e.g. Merabet et al., 2010).

Members of the laboratory in which the conservation of the name Sinorhizobium was proposed (Willems et al., 2003) have already faced the nomenclatural implications and refer to Ensifer (Martens et al., 2008). The subcommittee is offering no service to the rhizobial science community by not doing the same.

A final question is whether any ICSP subcommittee on taxonomy may contradict outright an interpretation of the Judicial Commission. Of course, interpretations of the Judicial Commission may be formally revisited, as for the proper orthography of Streptomyces scabies (Lambert et al., 2007), but contradiction without explanation is corrosive of nomenclatural order. Is this permissible?

The subcommittee has declared its intention to comment on all nodulating, nitrogen-fixing species in genera including those outside the family Rhizobiaceae, such as the genera Burkholderia and Ralstonia, both of which also contain organisms considered to pose clinical threats, such as Burkholderia cepacia, B. mallei, B. pseudomallei and Ralstonia pickettii (Lindström \& Martínez-Romero, 2005; Lindström \& Young, 2009). Neither of these genera is overseen by another ICSP taxonomy subcommittee. It is difficult to understand how a subcommittee can comment on the nomenclature of individual species except in the context of the nomenclature of the entire genus. Other scientists with an interest in these taxa because of their medical associations may be disconcerted if genera containing human pathogens are the subject of authoritative comment by a subcommittee that has little interest in such issues.

This taxonomic subcommittee is clearly more focused on supporting stable names for an ecological group of bacteria for practical purposes than on explaining the value of formal nomenclature. It is not surprising that the rhizobial science community is confused by the particular nomenclatural points, which have been an on-going source of misunderstanding in the bacteriological community at large (Young, 2008). What is surprising is that the subcommittee does not see its responsibility for endorsing and explaining these points as essential. In failing to do so they will cause much more confusion and misunderstanding in the community that they aim to serve.

\section{References}

Judicial Commission (2008). Opinion 84 - The genus name Sinorhizobium Chen et al. 1988 is a later synonym of Ensifer Casida 1982 and is not conserved over the latter genus name, and the species 
name 'Sinorhizobium adhaerens' is not validly published. Int J Syst Evol Microbiol 58, 1973.

Labeda, D. P. (2000). International Committee on Systematic Bacteriology; IXth International (IUMS) Congress of Bacteriology and Applied Microbiology. Int J Syst Evol Microbiol 50, 2245-2247.

Lambert, D. H., Loria, R., Labeda, D. P. \& Saddler, G. S. (2007). Recommendation for the conservation of the name Streptomyces scabies. Request for an Opinion. Int J Syst Evol Microbiol 57, 2447-2448.

Lapage, S. P., Sneath, P. H. A., Lessel, E. F., Skerman, V. B. D., Seeliger, H. P. R. \& Clark, W. A. (editors) (1992). International Code of Nomenclature of Bacteria (1990 Revision). Bacteriological Code. Washington, DC: American Society for Microbiology.

Lindström, K. \& Martínez-Romero, M. E. (2002). International Committee on Systematics of Prokaryotes Subcommittee on the taxonomy of Agrobacterium and Rhizobium. Minutes of the meeting, 4 July 2001, Hamilton, Canada. Int J Syst Evol Microbiol 52, 2337.

Lindström, K. \& Martínez-Romero, M. E. (2005). International Committee on Systematics of Prokaryotes Subcommittee on the taxonomy of Agrobacterium and Rhizobium. Minutes of the meeting, 26 July 2004, Toulouse, France. Int J Syst Evol Microbiol 55, 1383.

Lindström, K. \& Young, J. P. W. (2009). International Committee on Systematics of Prokaryotes Subcommittee on the taxonomy of Agrobacterium and Rhizobium. Minutes of the meeting, 31 August 2008, Gent, Belgium. Int J Syst Evol Microbiol 59, 921-922.
Martens, M., Dawyndt, P., Coopman, R., Gillis, M., De Vos, P. \& Willems, A. (2008). Advantages of multilocus sequence analysis for taxonomic studies: a case study using 10 housekeeping genes in the genus Ensifer (including former Sinorhizobium). Int J Syst Evol Microbiol 58, 200-214.

Merabet, C., Martens, M., Mahdhi, M., Zakhia, F., Sy, A., Le Roux, C., Domergue, O., Coopman, R., Bekki, A. \& other authors (2010). Multilocus sequence analysis of root nodule isolates from Lotus arabicus (Senegal), Lotus creticus, Argyrolobium uniflorum and Medicago sativa (Tunisia) and description of Ensifer numidicus sp. nov. and Ensifer garamanticus sp. nov. Int J Syst Evol Microbiol 60, 664-674.

Sneath, P. H. A. (2005). Bacterial nomenclature. In Bergey's Manual of Systematic Bacteriology - The Proteobacteria, vol. 2a, 2nd edn, pp. 8388. Edited by D. J. Brenner, N. R. Krieg \& J. T. Staley. New York, USA: Springer.

Willems, A., Manuel Fernández-López, M., Muñoz-Adelantado, E., Goris, J., De Vos, P., Martínez-Romero, E., Toro, N. \& Gillis, G. (2003). Description of new Ensifer strains from nodules and proposal to transfer Ensifer adhaerens Casida 1982 to Sinorhizobium as Sinorhizobium adhaerens comb. nov. Request for an Opinion. Int $J$ Syst Evol Microbiol 53, 1207-1217.

Young, J. M. (2008). An overview of bacterial nomenclature with special reference to plant pathogens. Syst Appl Microbiol 31, 405-424. 